\title{
Chinese talismans as a source of lead exposure
}

\author{
CK Chan *, CK Ching, FL Lau, HK Lee
}

\section{A B S T R A C T}

We describe a case of lead exposure after prolonged intake of ashes from burnt Chinese talismans. A 41-year-old woman presented with elevated blood lead level during screening for treatable causes of progressive weakness in her four limbs, clinically compatible with motor neuron disease. The source of lead exposure was confirmed to be Chinese talismans obtained from a religious practitioner in China. The patient was instructed to burn the Chinese talismans to ashes, and ingest the ashes dissolved in water, daily for about 1 month. Analysis of the Chinese talismans revealed a lead concentration of $17342 \mu \mathrm{g} / \mathrm{g}$ (ppm).
Hong Kong Med J 2014;20:347-9

DOI: $10.12809 / \mathrm{hkmj} 144235$

${ }^{1}$ CK Chan *, Dip Clin Tox, FHKAM (Emergency Medicine)

${ }^{2}$ CK Ching, FRCPA, FHKAM (Pathology)

${ }^{1}$ FL Lau, FRCS (Edin), FHKAM (Emergency Medicine)

${ }^{3}$ HK Lee, MSc

Hong Kong Poison Information Centre, United Christian Hospital, Kwun Tong, Hong Kong

${ }^{2}$ Hospital Authority Toxicology Reference Laboratory, Princess Margaret Hospital, Laichikok, Hong Kong

${ }^{3}$ Department of Clinical Pathology, Tuen Mun Hospital, Tuen Mun, Hong Kong

*Corresponding author: chanck3@ha.org.hk

\section{Case report}

Chinese talisman is a religious handwriting or calligraphy which is believed to possess magical powers for expelling evils and avoiding misfortune. It is usually obtained from Daoism religious practitioners. ${ }^{1}$ Some people believe that consuming burnt Chinese talisman ashes dissolved in water is useful in curing diseases. Here we report a case of lead exposure after prolonged intake of ashes from burnt Chinese talismans.

The patient was a 41-year-old woman. She presented with progressive weakness of four limbs with signs of upper motor neuron disease (MND) since March 2012. Electromyogram findings were compatible with diffuse anterior horn cell disorder. Motor neuron disease was clinically diagnosed by the treating neurologist. Knowing that no curative option exists for MND, she started using Chinese talismans obtained from a religious practitioner in China (Fig). She was instructed to burn the Chinese talismans to ashes and ingest the ashes dissolved in water 3 times daily. She continued this practice for about 1 month, until she believed that it was not useful for her illness. She was then found to have elevated blood lead level (BLL) of $1.83 \mu \mathrm{mol} / \mathrm{L}$ or $38 \mu \mathrm{g} / \mathrm{dL}$ (reference level, $<0.48 \mu \mathrm{mol} / \mathrm{L}$ or $<10 \mu \mathrm{g} / \mathrm{dL}$ ) during routine screening for treatable causes of neuropathy. Her blood mercury level was normal. Blood lead level rechecked 2 weeks later was 2.61 $\mu \mathrm{mol} / \mathrm{L}(54 \mu \mathrm{g} / \mathrm{dL})$. Other than the neurological symptoms, the patient had no other clinical features of lead poisoning such as elevated blood pressure, anaemia with basophilic stippling, or gastrointestinal symptoms. She was subsequently referred to the poison centre for assessment of lead exposure.
Detailed enquiry did not point to any wellknown source of lead exposure. She had been

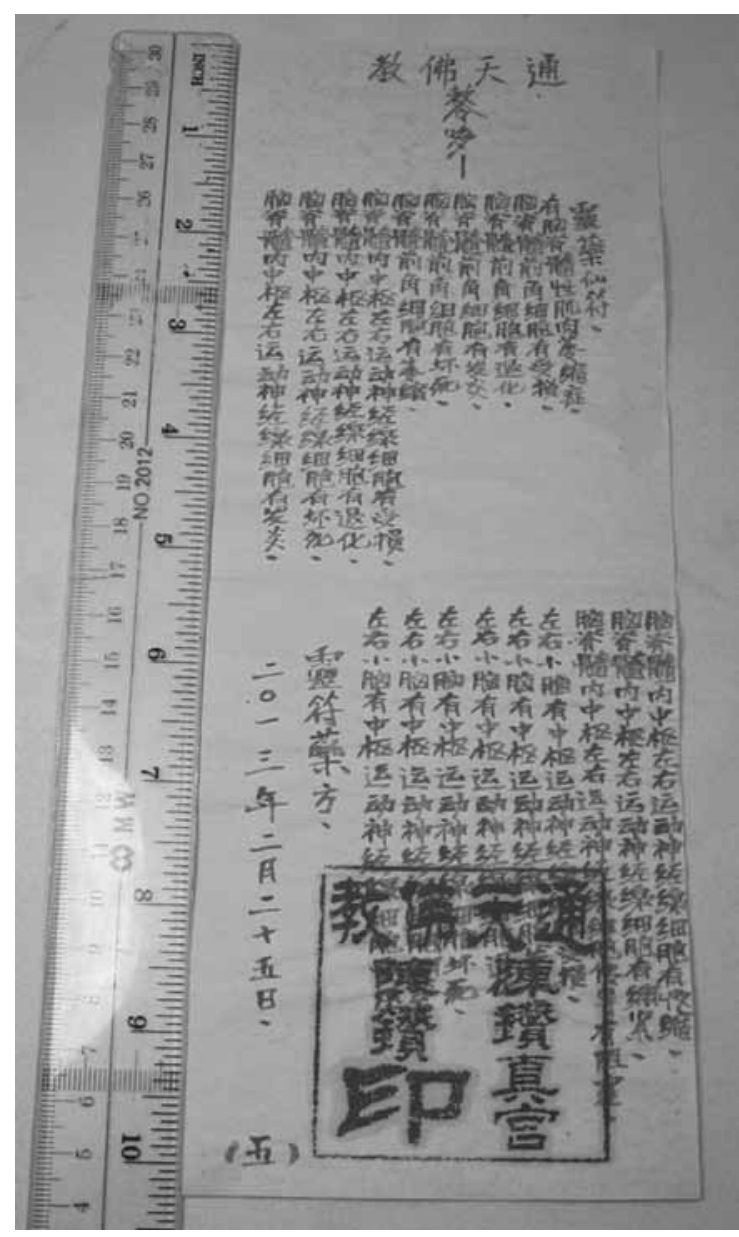

FIG. Chinese talisman used by our patient for expelling the evil of motor neuron disease 


\section{中國紙符成為鉛接觸的源頭}

陳志強、程楚君、劉飛龍、李漢傑

本文報告一宗因長期攝入中國紙符灰而引致鉛接觸的病例。一名 41 歲 女性出現漸進性四肢無力, 臨床上診斷為運動神經元病。病人檢查後 發現其血鉛水平上升。鉛接觸的源頭證實為病人從中國一位佛醫取得 的紙符, 她每天把紙符燒成灰並混與開水服用約一個月。分析紙符的 成份顯示每克紙符含鉛量為17342微克（ppm）。 working as a cleansing worker in a food-processing factory until she became sick. She had never worked in any mining industry, metal refinery, glass factory, or battery factory. She did not have a history of gunshot wound, nor did she have exposure to lead paint or ceramic craft. Her husband had normal BLL. Abdominal X-ray did not reveal lead-containing foreign materials in the gastro-intestinal tract. She had used several health supplements including vitamin preparations and ginkgo biloba extract. The lead levels of these health supplements were found to be undetectable. Our suspicions were aroused when the patient reported that the Chinese talismans were supposed to be written with cinnabar (硃砂), a red mercuric sulfide containing ore. Substitution of cinnabar with another red mineral, minium (鉛丹, lead tetroxide), when used as Chinese medicine, has been reported. 2,3 Analysis of the Chinese talisman by inductively coupled plasma mass spectrometry revealed a very high lead concentration of $17342 \mu \mathrm{g} / \mathrm{g}$, thus confirming the source of lead exposure.

Her BLL was $2.82 \mu \mathrm{mol} / \mathrm{L}(59 \mu \mathrm{g} / \mathrm{dL})$ about 2 months after stopping the use of the Chinese talismans. Although her neurological presentation was not typical of lead neurotoxicity, ${ }^{4}$ there have been case reports of lead poisoning mimicking MND., Moreover, an animal study showed that anterior horn cells were sensitive to lead toxicity. ${ }^{7}$ Chelation therapy with succimer (dimercaptosuccinic acid [DMSA]) was started in view of these possibilities. A standard course of DMSA $10 \mathrm{mg} / \mathrm{kg} 3$ times daily for 5 days, followed by 2 times daily for 14 days was given. ${ }^{8}$ Her BLL taken at 6 weeks after completion of DMSA course was $0.7 \mu \mathrm{mol} / \mathrm{L}(14 \mu \mathrm{g} / \mathrm{dL})$. No improvement of limb weakness was observed in the patient 8 weeks after completion of DMSA course. Further courses of DMSA were judged unnecessary. The patient continued to have medical follow-up for MND.

\section{Discussion}

This case illustrates a rare source of lead exposure related to the religious practice of consuming burnt Chinese talisman ashes dissolved in water to cure a disease. The list of common sources of lead exposure such as occupational, environmental and recreational ones, can be found in general medicine and toxicology textbooks. ${ }^{4}$ Uncommon and exotic sources reported in the literature usually involve traditional medicines, cosmetics, and ingestion of lead-containing foreign bodies (eg bullet, necklace, fishing sinker). ${ }^{9-11}$

The use of cinnabar has been described in Daoism alchemy and traditional Chinese medicine. ${ }^{12,13}$ Both lead tetroxide and cinnabar are red in colour with similar appearance, and substitution of cinnabar with lead tetroxide in Chinese medicine has been reported. ${ }^{3}$ The reason for the substitution is uncertain but it could be due to mixing up or related to the higher cost of cinnabar. ${ }^{2}$ The toxicity of lead tetroxide is known since ancient times in China. Lead poisoning related to the topical use of lead tetroxide in Chinese medicine for chronic ulcer has been reported..$^{12}$

Before the era of molecular genetics, lead poisoning was believed to be one of the possible causes of MND. ${ }^{14,15}$ Nowadays, with the identification of different genes implicated in MND, it is believed that genetic causes account for a significant proportion of the cases. ${ }^{16}$ Neurological presentation of mild lead poisoning includes tiredness, headache, insomnia, memory loss, and lessened interest in leisure activities. In severe cases, coma, seizures, and peripheral neuropathy are possible. ${ }^{4}$ Leadinduced peripheral neuropathy is typically a pure motor disorder with features including footdrop and wristdrop. ${ }^{4}$ Severe form of lead-induced peripheral neuropathy has been reported in causing generalised weakness mimicking MND., ${ }^{5,6}$ Unlike MND, leadinduced peripheral neuropathy is associated with increased body burden of lead, a temporal sequence between lead exposure and progression of muscle weakness, clinical stabilisation or remission after removal from exposure, and systemic involvement with other features of lead poisoning such as anaemia and gastro-intestinal disturbance. ${ }^{17}$

Chelation therapy is usually not indicated in asymptomatic adults with BLL of $<3.36 \mu \mathrm{mol} / \mathrm{L}$ $(70 \mu \mathrm{g} / \mathrm{dL})^{4,18}$ Nevertheless, there is no established action level in the presence of underlying MND. As lead-induced peripheral neuropathy is a possible reversible cause in this patient, chelation therapy was offered despite only a moderate increase in BLL. The lack of clinical improvement after cessation of exposure and normalisation of BLL made the diagnosis of lead-induced peripheral neuropathy unlikely in this patient.

\section{Conclusion}

Ingestion of burnt Chinese talisman is a possible source of lead exposure. This rare source of lead 
poisoning should be considered in a specific group of patients believing in this religious practice.

\section{References}

1. Wu YM. Talismans and spells. Available from: http:// taiwanpedia.culture.tw/en/content?ID=2073. Accessed 18 Sep 2013.

2. Ban of cinnabar in Chinese medicine use in Taiwan [in Chinese]. Available from: http://www.twtcm.com.tw/lawcontent.php?id=9. Accessed 26 Jun 2014.

3. Lead and mercury content of proprietary Chinese medicine Babao powder [in Chinese]. Available from: http://www. consumers.org.tw/unit412.aspx?id=459. Accessed $11 \mathrm{Dec}$ 2013.

4. Nelson LS, Lewin NA, Howland MA, Hoffman RS, Goldfrank LR, Flomenbaum NE. Goldfrank's toxicological emergencies, 9th ed. New York, NY: McGraw-Hill Medical; 2011: 1266-83.

5. Boothby JA, DeJesus PV, Rowland LP. Reversible forms of motor neuron disease. Lead "neuritis". Arch Neurol 1974;31:18-23.

6. Rubens O, Logina I, Kravale I, Eglîte M, Donaghy M. Peripheral neuropathy in chronic occupational inorganic lead exposure: a clinical and electrophysiological study. J Neurol Neurosurg Psychiatry 2001;71:200-4.

7. Yokoyama K, Araki S, Akabayashi A, Kato T, Sakai T, Sato $\mathrm{H}$. Alternation of glucose metabolism in the spinal cord of experimental lead poisoning rats: microdetermination of glucose utilization rate and distribution volume. Ind Health 2000;38:221-3.
8. Rogan WJ, Dietrich KN, Ware JH, et al. The effect of chelation therapy with succimer on neuropsychological development in children exposed to lead. N Engl J Med 2001;344:1421-6.

9. Karri SK, Saper RB, Kales SN. Lead encephalopathy due to traditional medicines. Curr Drug Saf 2008;3:54-9.

10. Levin R, Brown MJ, Kashtock ME, et al. Lead exposures in U.S. children, 2008: implications for prevention. Environ Health Perspect 2008;116:1285-93.

11. St Clair WS, Benjamin J. Lead intoxication from ingestion of fishing sinkers: a case study and review of the literature. Clin Pediatr (Phila) 2008;47:66-70.

12. Wu ML, Deng JF, Lin KP, Tsai WJ. Lead, mercury, and arsenic poisoning due to topical use of traditional Chinese medicines. Am J Med 2013;126:451-4.

13. Hsiao CM. Dao of alchemy. Available from: http:// taiwanpedia.culture.tw/en/content?ID=2081. Accessed 18 Sep 2013.

14. Lead and motor neurone disease. BMJ 1978;2:308.

15. Kamel F, Umbach DM, Munsat TL, Shefner JM, Hu $\mathrm{H}$, Sandler DP. Lead exposure and amyotrophic lateral sclerosis. Epidemiology 2002;13:311-9.

16. Rademakers R, van Blitterswijk M. Motor neuron disease in 2012: novel causal genes and disease modifiers. Nat Rev Neurol 2013;9:63-4.

17. Windebank A J, McCall JT, Dyck PJ. Metal neuropathy: peripheral neuropathy. 3rd ed. Philadelphia: WB Sanders; 1993: $1549-70$

18. Porru S, Alessio L. The use of chelating agents in occupational lead poisoning. Occup Med (Lond) 1996;46:41-8 